\title{
The Impact of Socially Responsible Marketing on TV Viewership and Household Conflicts: A Theoretical Descriptive Study
}

\author{
AHMED M. ASFAHANI \\ Human Resources Management Department \\ University of Business and Technology \\ Jeddah \\ SAUDI ARABIA
}

\begin{abstract}
Marketing is used by business organizations to promote the beneficial attributes of their product and services. The increased focus on promoting ethical and socially responsible business practices has contributed to the emergence of socially responsible marketing. This study explores this concept and how it promotes good/positive social and cultural norms. The research demonstrates how businesses are forced to practice socially responsible marketing though its impact on TV viewership and household conflict remains unknown. A qualitative descriptive study is carried out to examine the effect of socially responsible marketing on TV viewership and household conflict. Data was collected from a sample of 15 marketing experts using a selfadministered question and analyzed through thematic analysis. The study found no significant link between socially responsible marketing and TV viewership. Additionally, this research found that socially responsible marketing reduces household conflict. These findings are supported by the Uses and Gratification Theory, Functionalist Theory, and Conflict Theory.
\end{abstract}

Key-Words: socially responsible marketing, TV viewership, household conflict, marketing and advertising.

Received: July 18, 2021. Revised: December 11, 2021. Accepted: January 16, 2022. Published: January 18, 2022.

\section{Introduction}

Marketing basically focuses on promoting the beneficial attributes of a product or service based on societal values and beliefs. When marketing products/services, marketers ignore their harmful attributes because such information could damage public perception and affect the purpose of advertising. The marketing process is usually geared toward enabling the society digest new values developed by the marketer. As a result, marketers utilize various mediums to communicate the attributes of their products and services. Television advertising is one of the most commonly used marketing channels given its potential to reach a large target audience. Even though marketing seeks to influence the society regarding products/services, it ends up having a widespread impact on the society. Marketing is an avenue through which different societal ideals and values are shaped. The widespread impact of advertising has contributed to the emergence of the concept of socially responsible marketing, which helps promote positive societal values and ideals.

Socially responsible marketing is a concept that originates from corporate social responsibility, moral philosophy, institutional economics, and marketing history (Laczniak \& Shultz, 2020). This concept is based on three essential elements/components - stakeholder orientation, corporate citizenship, and social/ecological sustainability. These elements serve as the foundation for socially responsible marketing because they promote a pro-social instead of an instrumental-financial approach to marketing practice. Therefore, the concept of socially responsible marketing seeks to help create a better society and world. This idea was influenced by the widespread impact of marketing on the society and the world. By adopting socially responsible marketing, businesses would play a critical role in the development of a better society and world for all.

Landrum (2017) contends that socially responsible marketing has become increasingly critical in today's business world as millennials force brands to practice it. Millennials are forcing businesses to practice socially responsible marketing because they are more risk-averse and less like to spend their money unnecessarily. Unlike previous generations, millennials have a preference to do business with companies and business organizations that are prosocial messages, have ethical business standards, and adopt sustainable manufacturing techniques. Millennials' preference for socially responsible 
marketing has changed the advertising practices of many corporations and brands. Corporations and brands are increasingly exploring and embracing measures to practice socially responsible marketing in attempt to appeal to millennials and demonstrate corporate social responsibility.

\section{Statement of the Problem}

While socially responsible marketing is more preferred in today's society, its impact on TV viewership and household conflicts remains unknown. Media and advertising are generally agents of social change as they influence societal perceptions, ideals, and values. Millennials increasingly prefer socially responsible marketing since it's viewed as a tool for promoting positive societal ideals and values. As business organizations are increasingly looking for ways to practice socially responsible marketing, its impact on TV viewership and household conflicts is unknown. For businesses, the impact of socially responsible marketing on TV viewership is critical toward determining the effectiveness of their advertisements. For the society, the impact of socially responsible marketing on household conflicts is critical to determine its effectiveness in promoting good ideals and values in society. This study is an attempt to explore the link between socially responsible marketing and TV viewership and household conflict. Such exploration is critical to help determine the extent to which socially responsible marketing affects social and cultural values.

\subsection{Purpose of the Study}

The purpose of this study is to examine the role socially responsible marketing plays in TV viewership and household conflict. In this regard, this research seeks to establish how socially responsible marketing affects television viewership and household conflict. The assessment is based on the idea that marketing and advertising are agents of social change as they influence societal ideals and perceptions. As the demand for socially responsible marketing increases in the society, businesses and the general public needs to understand its impact on TV viewership and household conflict. Therefore, this research seeks to demonstrate how socially responsible marketing, TV viewership, and household conflict are linked or inter-related.

\subsection{Objectives of the Study}

The objectives of the study are:
1. To explore the concept of socially responsible marketing in today's business world.

2. To examine the impact of socially responsible marketing on social and cultural values in TV advertisements.

3. To evaluate the effect of socially responsible marketing on TV viewership and household conflict.

\subsection{Research Question}

To achieve the purpose and objectives of the study, this research seeks to answer the following research question:

RQ.1 What is the impact of socially responsible marketing on TV viewership and household conflict?

\section{Literature Review}

Marketing and advertising are agents of social change as they are used to reflect reality in general (Malik \& Shehzadi, 2017). Marketing is used to present the lifestyle of a specific class of society, which may not necessarily reflect the values and norms of the masses. However, marketing and advertising consciously and unconsciously affect moral values and social norms. According to Malik \&s Shehzadi (2017), the social and ethical fabric of the society is partly influenced by marketing and advertising.

Sama (2019) suggests that media advertisements have a significant impact on consumer behavior since they are the premise with which consumers develop perceptions regarding various products and services. Consequently, marketers utilize different media platforms to engage consumers in a distinct way and influence their behaviors. Hayko (2010) postulates that advertising shapes consumer behavior and influence social norms and ethical values by manipulating ideas of real-life situations, stereotyping, and playing with emotions. Through this, advertising has essentially reduced many people to the role of irrational consumers. Bellman et al. (2014) contend that advertising has contributed to the emergence of social TV, which entails the use of different communication devices and applications to connect with others. These researchers contend that marketing and advertising have both positive and negative impacts on individuals and the general society. Senthilkumar \& Venkatesh (2017) state that the impact of the media, particularly media advertisements, on the everyday lives of people has 
increased to a great extent as information technology continues to evolve.

\subsection{The Concept of Socially Responsible Marketing}

Socially responsible marketing is a concept whose origin can be traced back to the history of marketing, moral philosophy, corporate social responsibility, and institutional economics (Laczniak \& Schultz, 2020). Therefore, socially responsible marketing is a normative-ethical standard to advertising that has been influenced by the demands for corporate social responsibility and ethical standards in business practices. As a normative-ethical standard, socially responsible marketing plays a critical role in the development of socially responsible business enterprises in today's society. Ilic, Radnovic \& Zivkovic (2012) content that socially responsible marketing has emerged as a new way for businesses to address social responsibility. This new approach provides a framework for businesses to meet their own needs as well as cater to the interests and needs of the society. Businesses have a responsibility to help in solving problems or issues in the society, which has shaped the expectations of the society with regard to business organizations.

According to Gorokhova (2020), socially responsible marketing is a marketing philosophy and approach through which business organizations consider the best interests of the society both in the short- and long-term. In this case, business organizations make positive marketing decisions in consideration of the needs and interests of the society. Through this marketing approach, businesses go beyond communicating to customers and delivering products/services as they incorporate sustainable development and corporate social responsibility in marketing practices. Socially responsible marketing is commonly practiced by business organizations that implement corporate social responsibility principles as a means to show their positive environmental and social behavior for ethical consumers. By practicing socially responsible marketing, businesses demonstrate their commitment to take responsibility for their actions and aim to lessen the negative consequences of these activities (Jones, 2012). In essence, socially responsible marketing involves integrating social and ethical considerations into marketing practices and activities (Wibowo, Rohman \& Wijayanti, 2019).

\subsection{Television Viewership and the Effect of TV Advertising}

Sirgy et al. (2013) state that television viewership plays an important role in societal perception regarding the quality of life. For example, television viewership has been found to influence materialism and dissatisfaction with the standard of living. Television viewership plays a significant role in influencing people on whether they are happy or unhappy with their lives. The impact of television viewership on societal perception regarding the quality of life is linked to television marketing and advertising. Television marketing reinforces material consumption and possession through images that determine what is good life. According to Malik \& Shehzadi (2017), television advertising affects social and cultural norms, which shape societal perceptions regarding the quality of life.

Buijzen \& Valkenburg (2003) contend that television advertising has an impact on materialism and unhappiness relating to the quality of life. This effect is attributable to the link between media consumption and perceptions regarding social reality (Shrum, 2002). Media consumption shapes perceptions regarding social reality through images that portray different aspects of life (Mehraj, Bhat \& Mehraj, 2014). These images in turn affect a person's happiness with his/her life depending on what he/she possesses.

Damratoski et al. (2011) contend that television viewership has decreased in recent years because of rapid technological advancements. Technological advancements have contributed to the increased use of digital video recorders for television viewership. The increased use of the Internet for television viewership has affected viewership statistics and generated new demands for marketers. Livingstone (2009) argues that the conventional image of television viewership involving the family is no longer common because of the growing preference for the use of the Internet by younger generations. The increased use of the Internet and digital video recorders for television viewership has generated challenges to current television marketing and advertising.

Television viewership has been found to have a major impact on family image/ties through advertising and marketing (Wiscombe, 2014). The television family landscape was traditionally characterized by nuclear family configuration. However, modern television marketing has played a major role in shaping family configuration as singleparent families and a decline in reconstituted families are portrayed in television programs and advertisements. Television programs have 
contributed to increased exposure to violence, offensive language, and inappropriate sexuality (Canadian Pediatric Society, 2003). These factors are strongly linked to household conflict that has become common in today's society.

\section{Research Design, Methodology, and Approach}

Qualitative research methodology is commonly used for studies that are exploratory, descriptive or explanatory (Creswell, 2014). This research methodology is suitable for studies that seek to answer what, why, and how questions. Since the issue under investigation is exploratory in nature, a qualitative descriptive study approach was employed. A theoretical descriptive study was used to examine the effect of socially responsible marketing on TV viewership and household conflicts. According to Lambert \& Lambert (2012), qualitative descriptive research approaches focus on identifying the nature of specific events or issues being studied. Through this, the researcher provides an accurate description of the research problem or issue. In this case, this study provides an accurate description of how socially responsible marketing affects television viewership and household conflict based on sociological theories.

\subsection{Sample/Data}

A sample of 15 study participants was identified through convenient sampling approach. Using this sampling approach, the researchers identified a group of 15 marketing experts from his professional network. Etikan, Musa \& Alkassim (2015) contend that convenient sampling approach is a technique through which the researcher identifies a study sample from people who are easily available/accessible to $\mathrm{him} / \mathrm{her}$. This sampling approach was utilized because of the time- and resource-constraints in conducting the research. Data was collected from these participants using a self-administered questionnaire. The questionnaire was selected because of the high probability of a $100 \%$ response rate and administered online. After identifying the group of participants, the researcher explained the purpose of the study and its objectives. The questionnaire was then administered online and participants requested to complete it within two weeks. The researcher achieved a $100 \%$ response rate from these participants.

\subsection{Data Analysis}

The self-administered questionnaire comprised of open-ended questions on the research issue. Once data was obtained from the participants, thematic analysis was used to identify emerging themes and patterns in the dataset. These emerging themes and patterns were then classified into different categories depending on how they are inter-related. The different categories of emerging themes/patterns were used to answer the research question and achieve the purpose of the study.

\section{Findings}

One of the categories of emerging themes in the dataset is the view of socially responsible marketing as an ethical and socially responsible marketing philosophy and approach. Study participants opined that socially responsible marketing seeks to promote good social and cultural norms that contribute to a better society and world. They contend that socially responsible marketing has become critical for modern businesses because of the increased focus on promoting ethical business practices. Moreover, consumers are increasingly preferring to engage with businesses that model social and ethical responsibility in their actions, which has forced companies to explore ways to implement socially responsible marketing.

Secondly, the dataset demonstrated that there is a relatively minimal impact of socially responsible marketing on TV viewership. $87 \%$ of the study participants (13 out of 15) stated that TV viewership is affected by various factors that are not necessarily linked to television marketing and advertising. They contend that the proliferation of technological devices and applications as well as the growth of social media have affected TV viewership.

Third, the dataset showed a relatively strong link between socially responsible marketing and reduced household conflict. As companies embrace socially responsible marketing practices, they promote ideals and values for a better society and world, which in turn minimize exposure to violence and reduces household conflict.

\subsection{Discussion}

The study's findings suggest that there is no significant relationship between television marketing and viewership. As shown in these findings, socially responsible marketing does not necessarily affect TV viewership. TV viewership is influenced by other factors such as the emergence of social media and increased use of technological 
devices/apps. This finding is supported by the Uses and Gratifications (U\&G) Theory, which suggests that people select media and content to meet their needs or wants (Cha, 2016; Papacharissi, n.d.). Based on this theory, media usage is dependent on individuals' perception of how it meets their needs (Karimi et al., 2014; Mehrad \& Tajer, 2016). Therefore, television viewership is not attributable to the kind of marketing adopted by companies, but by its ability to fulfill people's needs. People increasingly use social media because it's associated with significant gratifications (Hossain, 2019). As a result, there is no link between socially responsible marketing and TV viewership.

Secondly, the study shows a significant link between television marketing and household conflict. As evident in the dataset, socially responsible marketing contributes to reduced household conflict by promoting positive social ideals and values. This finding is supported by Functionalist Theory, which is one of the theoretical perspectives that guide sociological thinking on societal problems or challenges (Creative Commons, 2010). This theory postulates that the establishment of a strong society requires social stability, which is a by-product of adequate socialization and social integration (Crossman, 2020). In this regard, socially responsible marketing promotes social values and ideals that seek to create social stability resulting in reduced household conflict. By incorporating societal needs and interests, socially responsible marketing helps to reduce household conflict. Conflict Theory postulates that conflict is a by-product of power inequalities and imbalances (Creative Commons, 2010; OpenStax CNX, n.d.). Socially responsible marketing addresses these inequalities by ensuring businesses cater to society's needs and interests.

\section{Conclusion}

In conclusion, mass media plays an important role in the society as it helps to inform, educate, and entertain. Businesses are increasingly using mass media to communicate to the target audience through advertising and marketing. Television advertising is one of the most commonly used forms of marketing by corporations and brands. Socially responsible marketing has become an important component of modern television advertising because of the increased focus on ethical and socially responsible business practices. As businesses are increasingly exploring how to implement socially responsible marketing, its impact on TV viewership and household conflict remains relatively unknown.
This study explored the issue and found no significant link between socially responsible marketing and TV viewership. However, the study found a strong link between television marketing and household conflict. In this case, socially responsible marketing helps to lessen household conflict by promoting good ideals and values.

\section{References:}

[1] Bellman, S., Robinson, J.A., Wooley, B. \& Varan, D. (2014, December). The effects of social TV on television advertising effectiveness. Journal of Marketing Communications, 23(1), 1-19.

[2] Buijzen, M. \& Valkenburg, P.M. (2003, September). The effects of television advertising on materialism, parent-child conflict, and unhappiness: A review of research. Journal of Applied Developmental Psychology, 24(4), 437-456.

[3] Canadian Pediatric Society. (2003, May-June). Impact of media use on children and youth. Pediatrics Child Health, 8(5), 301-306.

[4] Cha, J. (2016, February 1). Television use in the 21st Century: An exploration of television and social television use in a multiplatform environment. First Monday, 21(2). Retrieved from https://firstmonday.org/article/view/6112/5199

[5] Creswell, J.W. (2014). Research Design: Qualitative, Quantitative, and Mixed Methods Approaches. Thousand Oaks, CA: SAGE Publications Inc.

[6] Crossman, A. (2020, January 24). Understanding Functionalist Theory. Retrieved February 17, 2021, from https://www.thoughtco.com/functionalistperspective-3026625

[7] Creative Commons. (2010). Social problems: Continuity and change. Retrieved February 17, 2021, from https://open.lib.umn.edu/socialproblems/chapter/12-sociological-perspectives-on-socialproblems/\#: : text=Three\%20theoretical\%20perspec tives $\% 20$ guide $\% 20$ sociological, $\mathrm{do} \% 20$ so $\% 20 \mathrm{in} \% 2$ 0different $\% 20$ ways.

[8] Damratoski, K.J., Field, A.R., Mizell, K.N. \& Budden, M.C. (2011, January/February). An investigation into alternative television viewership habits of college students. The Journal of Applied Business Research, 27(1), 69-76.

[9] Etikan, I., Musa, S.A. \& Alkassim, R.S. (2015). Comparison of convenience sampling and purposive sampling. American Journal of Theoretical and Applied Statistics, 5(1), 1-4.

[10] Gorokhova, T. (2020). The development of socially responsible marketing as a consequent effect of the socio-economic transformation in the society. Public Order Research Journal, 24, 448457. 
[11] Hayko, G (2020). Effects of advertising on society: A literary review. HOHONU, 8, 79-82.

[12] Hossain, M.A. (2019, April 8). Effects of uses and gratifications on social media use: The Facebook case with multiple mediator analysis. PSU Research Review, 3(1), 16-28.

[13] Ilic, M., Radnovic, B. \& Zivkovic, Z.D. (2012, December). Socially responsible marketing: Yesterday and today. Journal of Economic Development Environment and People, 1(3), 59-73.

[14] Jones, E. (2012). Socially responsible marketing. Retrieved from Holy Cross College website: https://www.holycross.edu/sites/default/files/files/s ociologyanthropology/faculty/jones/jonessr_marketing_greenwashing.pdf

[15] Karimi, L., Khodabandelou, R., Ehsani, M. \& Ahmad, M. (2014). Applying the Uses and Gratification Theory to compare higher education students' motivation for using social networking sites: Experiences from Iran, Malaysia, United Kingdom, and South Africa. Contemporary Educational Technology, 5(1), 53-72.

[16] Laczniak, G. \& Schultz, C. (2020, November 24). Toward a doctrine of socially responsible marketing (SRM): A macro and normative-ethical perspective. Journal of Macromarketing. DOI: 10.1177/0276146720963682

[17] Lambert, V.A. \& Lambert, C.E. (2012). Qualitative descriptive research: An acceptable design." Pacific Rim International Journal of Nursing Research, 16(4), 255-256.

[18] Landrum, S. (2017, March 17). Millennials driving brands to practice socially responsible marketing. Forbes. Retrieved from https://www.forbes.com/sites/sarahlandrum/2017/0 3/17/millennials-driving-brands-to-practicesocially-responsible-marketing/?sh=5eb774064990

[19] Livingstone, S. (2009). Half a century of television in the lives of our children. The ANNALS of the American Academy of Political and Social Science, 625, 151-163.

[20] Malik, S.A. \& Shehzadi, S. (2017). Effects of TV commercials on social and cultural norms: An analysis of viewer's perceptions. News Media and Mass Communication, 63, 46-54.

[21] Mehrad, J. \& Tajer, P. (2016). Uses and Gratification Theory in connection with knowledge and information science: A proposed conceptual model. International Journal of Information Science and Management, 14(2), 1-14.

[22] Mehraj, H.K., Bhat, A.N. \& Mehraj, H.R. (2014, June). Impacts of media on society: A sociological perspective. International Journal of Humanities and Social Science Invention, 3(6), 56-64.

[23] OpenStax CNX. (n.d.). Theoretical perspectives on media and technology. Retrieved February 17, 2021, from https://courses.lumenlearning.com/sociology/chapte r/theoretical-perspectives-on-media-andtechnology/
[24] Papacharissi, Z. (n.d.). Uses and gratifications. Retrieved from University of Illinois at Chicago website:

https://zizi.people.uic.edu/Site/Research_files/Papac harissiU\%26G.pdf

[25] Sama, R. (2019, February 13). Impact of media advertisements on consumer behavior. Journal of Creative Communications, 14(1), 54-68.

[26] Senthilkumar, N. \& Venkatesh, S. (2017, April). Impact of television media in influencing consumer buying behavior through humorous advertisements. Online Journal of Communication and Media Technologies, 7(2), 71-95.

[27] Shrum, L.J. (2002, January). Media consumption and perceptions of social reality: Effects and underlying processes. In Media effects: Advances in theory and research (chap. 4, pp.69-96).

[28] Sirgy, M.J., Lee, D., Kosenko, R. \& Meadow, H.L. (2013, May). Does television viewership play a role in the perception of quality of life? Journal of Advertising, 27(1), 125-142.

[29] Wibowo, M.K., Rohman, F. \& Wijayanti, R. (2019, January). The effect of socially responsible marketing on corporate reputation at Pt Bank Negara Indonesia in Malang Regency (study on branchless banking agent in Pt Bni). International Journal of Scientific and Technology Research, 8(1), 113-118.

[30] Wiscombe, S.A. (2014). Family ties: A profile of television family configurations, 2004-2013. Retrieved from Brigham Young University website: https://scholarsarchive.byu.edu/cgi/viewcontent.cgi ?article $=5347 \&$ context $=$ etd

\section{Creative Commons Attribution License 4.0 (Attribution 4.0 International, CC BY 4.0)}

This article is published under the terms of the Creative Commons Attribution License 4.0 https://creativecommons.org/licenses/by/4.0/deed.en US 